\title{
Edwards, Louise, Elaine Jeffreys (eds.), Celebrity in China
}

Hong Kong, Hong Kong University Press, 2010, 286 pp.

Hai Ren

\section{(2) OpenEdition}

\section{Journals}

Electronic version

URL: http://journals.openedition.org/chinaperspectives/5487

DOI: $10.4000 /$ chinaperspectives. 5487

ISSN: 1996-4617

\section{Publisher}

Centre d'étude français sur la Chine contemporaine

Printed version

Date of publication: 1 January 2011

Number of pages: 94-95

ISSN: 2070-3449

\section{Electronic reference}

Hai Ren, «Edwards, Louise, Elaine Jeffreys (eds.), Celebrity in China », China Perspectives [Online], 2011/1 | 2011, Online since 30 March 2011, connection on 23 September 2020. URL : http:// journals.openedition.org/chinaperspectives/5487; DOI : https://doi.org/10.4000/chinaperspectives. 5487

This text was automatically generated on 23 September 2020.

(c) All rights reserved 


\section{Edwards, Louise, Elaine Jeffreys (eds.), Celebrity in China}

Hong Kong, Hong Kong University Press, 2010, 286 pp.

Hai Ren

1 The book is a collection of studies of celebrity in contemporary China. The introductory chapter provides an overview of the scholarly literature on celebrity in Australia, European countries, and the United States, discusses its implications in studying celebrity in China, and explores major themes in the emerging field of celebrity studies in China. The rest of the book includes a series of case studies. The first two cases, military heroes and celebrity mothers, highlight the roles of the Communist Party-state in deploying publicity as a state apparatus. This is followed by cases of celebrities produced through a mixture of governmental and non-governmental processes. They include "chastity heroines" and celebrity HIV/AIDS

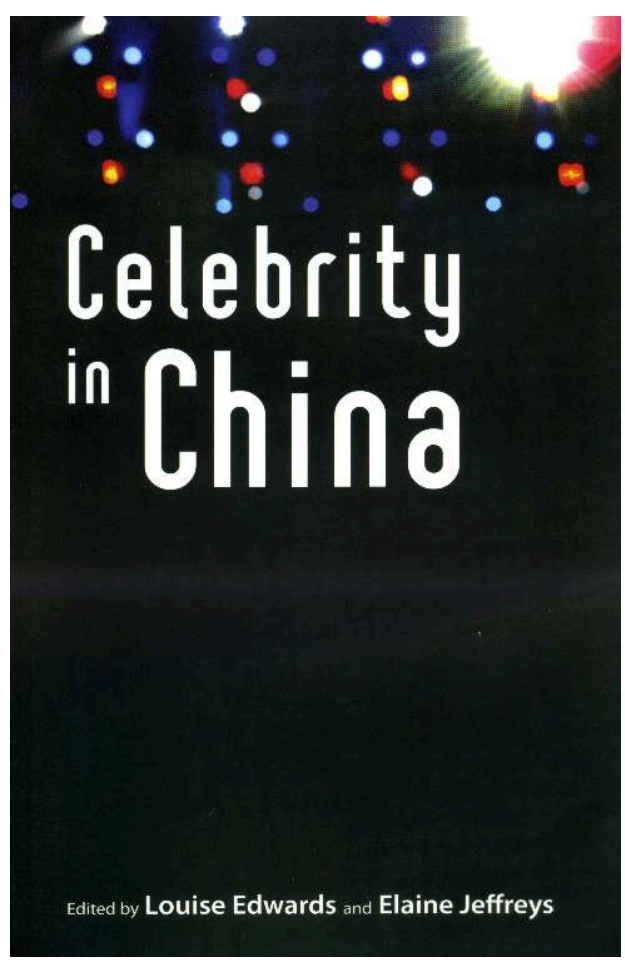
activists. Moreover, the book also includes two types of popular culture cases that show successful trajectories in their lives. One deals with celebrities in relation to popular cultural production, for example, Jet Li in film and sports, popular novelists, and ethnic minority musicians. The other type of case examines the links between successful people and their celebrity status, as well as their effect on Chinese 
society. These cases include a celebrated transsexual dancer, well-known entrepreneurs, and popular Internet bloggers.

2 Collectively, the authors of the book have made a significant contribution to popular culture studies in at least two major ways. The book produces materials and cases in China that may be compared with those in other countries and regions. As the editors point out, "China's celebrity culture is marked by the influence of the Party-state and a fusion of culturally embedded and socialist values, while also mirroring some aspects of global celebrity culture" (p. 15). Thus, a major issue highlighted by the book is "the diverse interactions between the Party-state and the commercial celebration of public individuals in China today" (ibid.). Louise Edwards's chapter on the military argues that the Party-state's use of commercial promotional culture promotes army general-heroes as models of "good citizenship" rather than "exemplary comradeship." Yingjie Guo's chapter argues that government-sponsored and media-led campaigns, as in the case of finding and promoting China's "Outstanding Mothers," capitalise on "the celebrity effect" in order to generate "social cohesion." Elaine Jeffreys' study of "chastity heroines" (women who attained frame and became sites for promoting charity after being crippled by leaping from high-storey buildings to escape forced prostitution) and Johanna Hood's chapter on the actor Pu Cunxin, who helps the government to educate the public in halting the spread of HIV/AIDS, also address the same general issue.

The book also fills a gap in the field of Chinese popular culture studies by providing a good overview of the issues and questions on celebrity in China. Given how influential Chinese celebrities have become in recent decades, the book collectively provides a good understanding of important issues for interested readers and scholars. Studies of celebrity offer clues to the ways in which social and moral values change. In Chinese society, such attributes as public propriety, group orientation, academic achievement, resilience, and thrift, are not only considered normative values, but also inform social processes. Celebrity may be seen as a good site for understanding social processes in which famous individuals transmit values to ordinary citizens. The book suggests a number of issues in this regard. First, state-sponsored celebrities promote these norms, as shown by military celebrities, model mothers, and famous actors. Second, individuals who are perceived to have overcome extraordinary odds to survive or to achieve success are also treated like celebrities - for example, women who escaped forced prostitution. Third, as in other parts of the world, some celebrities in China "are admired not only for their perseverance, accomplishments and good deeds, but also for their affluent lifestyles and status-giving consumption of luxury brand products" (p.18). Related cases include the novelist Wei Hui, author of Shanghai Baby (Shuyu Kong's chapter), the dancer Jin Xing (Gloria and M. E. Davies' chapter), and the real estate developer Wang Shi (David Davies' chapter). Fourth, philanthropic endeavours, whether informed by Buddhist notions of compassion, the Confucian virtue of humaneness, or other cultural traditions, are also becoming important for celebrities in China. One of the functions of celebrity philanthropy is to legitimise wealth distribution by mitigating the widespread resentment of those who appear to have come by their wealth too easily in China's historical transformation from a socialist country into a neoliberal state that combines both socialist and capitalist systems. ${ }^{1}$ Many of the book's chapters deal with philanthropy, public health, and corporate social responsibility. Finally, China's celebrities also show that normative values and ways of living can be derived from non-conformity and transgression ("immorality" in the 
book's language). These examples include Wang Shuo's and Wei Hui's works on sexual adventurism (Shuyu Kong's chapter), Jin Xing's transsexuality deployed in publicity and promotion (Gloria and M. E. Davies' chapter), and Furong Jiejie's online selfrepresentation (I. D. Roberts' chapter).

4 While finding many merits, I also have questions. First, what terms have emerged in China to refer to "celebrity?" The book mentions a few of them such as "figures" (renwu), "beautiful girls" (meinu), "handsome boys" (shuaige), and "name flowing" (mingliu). It would be helpful to discuss their origins and uses in popular culture. Second, if celebrity is closely tied to the production of social norms, what is the nature and status of celebrity as normative? How does celebrity make norms intelligible in their dissemination? How are celebrity-related norms compared with other kinds of norms such as statistical ones? What are the differences between the exemplary and the average? Finally, many celebrities in the book appear to be exemplary like the "models" (mofan) in socialist China, but are qualitatively different. No longer conforming to the Maoist standard of living, they now stand for the do-it-yourself way of life. Perhaps one of the most important and challenging questions for a celebrity study, whether in China or elsewhere, is this: What does living as a human being entail in a world fashioned by celebrities?

\section{NOTES}

1. Hai Ren, Neoliberalism and Culture in China and Hong Kong: The Countdown of Time, London, Routledge, 2010.

\section{AUTHOR}

\section{HAI REN}

Assistant Professor in the Department of East Asian Studies, University of Arizona. 